\title{
INNOVATION AND SOCIAL ENTREPRENEURSHIP AT THE BOTTOM OF THE PYRAMID - A CONCEPTUAL FRAMEWORK
}

Taimoor Pervez, Alex Maritz* and Anton de Waal

Faculty of Business and Enterprise, Swinburne University of Technology

\begin{abstract}
The research aims to identify key success criteria for innovations by enterprises targeting the bottom of the pyramid. Innovation, social entrepreneurship and the bottom of the economic pyramid are defined in the light of academic literature and their varied criteria are explored. The two different academic opinions on fortune or opportunity existing in the BOP markets are also contrasted. The research philosophy is based on realism and the research methodology selected is inductive. The data have been collected through secondary sources using case study strategy to present four cases of innovations by social or corporate enterprises at the BOP. The case studies have been chosen from a variable range in terms of BOP countries, social enterprises and multinational companies, for-profit or not-for-profit organisations, and product or business model innovations. Success criteria identified from case studies in the light of academic literature include going beyond selling to the poor, considering BOP groups as producers and BOP engagement. A conceptual framework has been developed from identified criteria and further recommendations for empirically testing the framework to turn it into a model have been provided.
\end{abstract}

Key words: bottom of the pyramid, base of the pyramid, innovation, entrepreneurship, disruptive innovation, social entrepreneurship

JEL: O310

\section{1}

\section{Introduction}

While poverty remains one of the key problems of the world, all other key issues in the developing world, such as malnutrition, health care and sanitation, seem to be interlinked with poverty and alleviating the economic misery of the poor continues to be one of the biggest challenges facing society at large (London \& Anupindi, 2012). On the other hand, academic scholars like C.K. Prahalad, Allen L. Hammond, and Stuart L. Hart have identified a lucrative multi-trillion dollar opportunity for enterprises and multinational companies of the developed world in these neglected and underdeveloped poor markets (Tiwari \& Herstatt, 2012). An unsolved problem in these emerging markets therefore presents a massive opportunity for the developed markets (Chakravarthy \& Coughlan, 2012) and a successful venture would not only produce enormous economic gains, but also solve the long-standing issue of poverty by responsibly using social inclusion to uplift millions out of poverty (Hall, Matos, Sheehan, \& Silvestre, 2012). The solution for such multifaceted success lies predominantly in innovation and entrepreneurship at BOP.

The dilemma for many enterprises, however, has been an inability to capture these markets and realise the fortune promised by these developing markets. In fact, similar types of innovation by enterprises at the BOP can lead to different and at times completely opposite results in terms of social and economic success or failure. The problem for enterprises lies in lack of understanding of the key value creation parameters and characteristics of success for innovations at BOP. The key research question to be addressed is: "What are the major factors for success or failure of innovations and social enterprises at the bottom of the pyramid?" To answer that question, this research paper aims to study cases where innovations were introduced at the BOP, looking for similar or varying patterns, with the aim of formulating a conceptual implementation 
framework for the potential success of such ventures. The outcome is a predictive conceptual framework for future innovations or social enterprises at the BOP as a guide to what can be successful. The contribution this paper intends to make to the body of knowledge is to fill the research gap in BOP literature by providing a consolidated conceptual framework of criteria for successful innovations by enterprises.

\section{2}

\section{Background / literature review}

\subsection{Bottom of the pyramid}

The term "bottom of the pyramid", also known as base of the pyramid, refers to the largest and poorest socio-economic group in the economic chain. Different authors and academics have set slightly different earning criteria to represent this economic bottom of the pyramid. The most widely used criterion has been the four billion people living in developing and emerging countries with a per capita income of under \$2,000 per year (Hall, Matos, Sheehan $\&$ Silvestre 2012) or below $\$ 3,000$ per annum in local purchasing power (Hammond, Kramer, Katz, Tran \& Walker, 2007; Subrahmanyan \& Gomez-Arias, 2008). Ahlstrom (2010) states that there is a population of several billion people at the lower end of the world markets who earn less than $\$ 1,500$ annually. The BOP has also been said to represent the 2.5 billion people in the world who live on less than US $\$ 2.5$ per day (Shah, 2008). Most of the people at the bottom of the economic pyramid are based in South Asia, Africa, Eastern Europe, the Caribbean and Latin America (Subrahmanyan \& Gomez-Arias, 2008).

The most prominent author on the subject is C. K. Prahalad from the University of Michigan who attracted attention with his initial article in 2002 and later his bestseller The Fortune at the Bottom of the Pyramid in 2004. According to him, BOP comprises a tier of four billion people with an annual per capita income of less than US $\$ 1,500$ or an income of under US \$1 per day (Prahalad \& Hart, 2002).

It is critical to focus on these BOP markets as such huge disparities in income are a significant challenge to successful industriali- sation and global integration. This challenge becomes all the more important as social exclusion of these majority populations in BOP markets causes a range of major problems like crime and corruption (Hall et al., 2012). Thus, collaborative inclusive policies encompassing both social and economic perspectives will eventually result in more fruitful entrepreneurial consequences.

\subsection{Fortune at the BOP}

Prahalad and Hart (2002) state that the BOP presents a huge opportunity for businesses, especially multinational companies as there is a possibility of converting the BOP market into a profitable venture capitalising on billions of potential customers joining commercial markets for the first time. Because this untapped market represents two-thirds of the world population, it would account for a multitrillion dollar industry. Prahalad claims that this figure is as high as $\$ 13$ trillion (Karnani, 2007). Even by conservative measures it is estimated at $\$ 5$ trillion (Subrahmanyan \& Gomez-Arias, 2008). The attractions go beyond mere growth and profits to incalculable to humankind in elevating billions of people out of poverty while creating an ideal environment for trying sustainable products and services to improve on historical mistakes.

\subsection{Misfortune at the BOP}

Karnani (2007) takes an alternative view of the opportunities at the BOP. He does not agree with Prahalad and most other authors in the field. He believes that it is a misconception that there are opportunities at the BOP and contends that there is no glory or fortune there, at least for multinational companies. He does admit that poverty is a serious global challenge that needs to be addressed. However, Karnani believes that the BOP is a fantasy and according to him the economic opportunity is not outstanding. He estimates it at $\$ 0.3$ trillion. $\mathrm{He}$ adds that the BOP is unlikely to be profitable for large multinational companies because of the costs associated with serving these markets.

Despite his opinions, Karnani (2007) does admit that there are success stories associated with selling to the BOP market. He argues, however, that to tackle the problem of poverty 
the people at the BOP need to be viewed as producers rather than consumers.

\subsection{Innovation}

The role of innovation as one of the most essential sustainable competitive advantages, if not the only one, cannot be denied. It is one of the pillars of enterprise (Baregheh Rowley, J., \& Sambrook, 2009; Empson, 2012; Govindarajan \& Ramamurti, 2011; Markides, 2012). Innovation has been defined by a number of scholars and authors in varying ways (Damanpour \& Schneider, 2008). The definition has evolved over time as people have attempted to generalise it and to make its scope broad enough to cover all its dimensions. A comprehensive review of the literature on innovation has revealed that the important characteristics required in defining innovation are the following:

1) "Newness" entirely or in the specific business, firm or organisation (Rogers, 1998; Thompson, 1965)

2) Successful commercialisation (Becker \& Whisler, 1967; Rogers, 1998)

3) There must be a new creation or significant improvement to existing practice (Baregheh et al., 2009)

4) It must span products, services or their delivery to the market/customers (business model) (Crossan \& Apaydin, 2010; Wong, Tjosvold \& Liu, 2009)

When the different definitions in the literature were compared with the listed criteria, it was observed that while all the definitions included some of the criteria, almost all missed out on a specific criterion or multiple criteria. The following consolidated definition is therefore provided:

Innovation is the process of applying a novel and creative solution to the specific field, to create something new or significantly improved, and successfully delivering its value to the intended market. Innovation can be incorporated into a product, service, process or the business model itself.

\subsection{Social entrepreneurship}

The major differentiator for social entrepreneurship is that unlike in corporate entrepreneurship, the main drive is to create "social value" instead of personal or shareholder wealth (Austin, Stevenson \& Wei-Skillern, 2006). While the primary purpose of a social enterprise is creating social value, that of a commercial enterprise is to create profits. With a social enterprise, on the other hand, profits may be a by-product of the operations but not the primary purpose. This means that a social enterprise, which attempts to create social value, may or may not be able to generate profits as well and enterprises may fulfil social needs and impart social value primarily in an attempt to generate profits. The success of a social enterprise can be judged only by the social value created (e.g. in case of not-forprofit organisations) and commercial enterprises may not create any social value at all, yet be very profitable and successful organisations.

Dees (1998) also believes that social entrepreneurs have a clear social mission which affects how they perceive and assess opportunities. So the endeavour to create social value is the main focus rather than wealth creation, which may only be a means to an end for social entrepreneurs, unlike business entrepreneurs, for whom wealth creation is the measure of value. Mair and Marti (2006) argue that social entrepreneurship can take place just as easily on a for-profit or not-for-profit (NFP) basis and the choice of business model is usually based on the social needs being addressed by the social enterprise.

While most theories have distinguished entrepreneurs from social entrepreneurs by financial gains, Martin and Osberg (2007) argue that even entrepreneurs are rarely motivated by financial gains as the odds on this are relatively low. Both entrepreneurs and social entrepreneurs are initially characterised by the identified opportunity and the pursuit of their innovative solution or vision. However, the distinction is that entrepreneurs create value for an assumed market that would buy the product or service and eventually for shareholders, whereas social entrepreneurs' value proposition is aimed at social upliftment of the underprivileged and neglected.

\section{3}

\section{Methodology}

The research philosophy (Saunders, 2012) for this study is based on "realism". It has its roots 
at the crossroads of "ontology" and "criticalism", where the research basis is historical realism shaped by social, political, cultural and economic values at the BOP, crystallised over time (Voros, 2008). The aim of the research lies in the domains of "positivism" and "post-positivism", in attempting to find an explanation of prediction and control according to Voros's (2008) paradigms, where paradigms are defined by Saunders (2012) as a way of examining social phenomena to gain a particular understanding of these phenomena and attempt explanations. The methodology selected for the paper is initially inductive, starting with a basic understanding of the way humans build their world, permitting alternative explanations and theories of this understanding within the context of the events and using a flexible variety of data collection methods (Saunders, 2012). Real-life cases are used to develop a conceptual framework supported by existing literature and arrive at a conceptual theory of success factors.

The research strategy used was the "case study" strategy with data collection based primarily on secondary sources such as academic literature, journal articles and books. Case study strategy was chosen as this strategy is considered to be very useful when answering the questions "why" and "how", particularly with real-life phenomena that are still evolving and developing (Eisenhardt, 1989; Tiwari \& Herstatt, 2012; Yin, 1981). Another important strength of using case study strategy is that it helps to build theory which is likely to be "novel". A case study strategy has other key strengths in theory building like testability and empirical validity because of the linking of the empirical evidence that emerges in different cases (Eisenhardt, 1989). Tiwari and Herstatt (2012) point out that multiple case studies are considered to be very effective in creating theory as they allow repetition and extension of similar constructs or patterns across different cases. Case selection is very important in building theory as it controls variation, defines limits of generalisability and helps to replicate emergent theory to confirm or disconfirm hypotheses (Eisenhardt, 1989; Yin, 1981). Multiple cases in similar scenarios were therefore chosen for the purposes of the paper so that similarities, differences and outcomes could be discussed and conclusions drawn from them. The cases selected are from corporate multinational companies, for-profit and not-for-profit social enterprises, a range of BOP countries, and include product, process and business model innovations to draw generalised conclusions.

Case studies involving innovations in different parts of the developing world have been compared, the proviso being that target markets in these different countries have reasonably similar social values and cultures for the purposes of comparison. These assumptions may be realistic, as the case studies are taken from different South Asian developing countries with a significant number of people living below the poverty line, and therefore falling into the BOP category, and having very similar cultures. Because of secondary data and geographic location constraints, the research is limited to a conceptual framework rather than an empirical model. This provides an opportunity and pathway for future research, however, and it is recommended that the framework should be empirically tested and developed into a model.

\section{4}

\section{Case studies}

A number of case studies of disruptive innovations at the BOP are discussed. They include both successful and failed ventures, with innovations in technology as well as business models, so the results can be generalised. We specifically identified nine organisations for the case studies, and after an initial prescreening by colleagues in the social innovation and entrepreneurship disciplines, three were chosen. These were deemed appropriate for providing an explanation and examples of divergence, geographical representation and BOP significance.

\subsection{Nestle Pakistan}

An excellent example of increasing productivity and efficiency in the BOP market by a multinational firm is that of Nestle in Pakistan (Nestle, 2013). Although Pakistan is the fifthlargest producer of milk in the world, because of inefficient milk collection methods most of the efforts of poor farmers have historically 
been wasted. As there was no infrastructure for refrigerated milk collection at the grass roots level for farmers who did not have the means or resources to transport or store the milk, middlemen controlled the market. As a result not only were farmers deprived of their due rewards, but the full potential of milk production could not be exploited as a lot was wasted because of inefficient collection and storage and refrigeration problems. The milk that finally reached the processing facilities in towns was already contaminated with preservatives, impairing the quality and reducing the shelf life of milk to four weeks compared to six months for Ultra High Temperature (UHT) processed milk in Europe. After Nestle entered the market in 1988, the milk collection process was overhauled and refrigerated collection centres were created in local villages within reach of farmers. This not only ensured that wastage and contamination were eliminated, but also helped local farmers reap the full benefits from their product and labour, and removed the middlemen. No farmer has to go far to deliver milk anymore and payment is prompt and transparent. The total volume of milk purchased by Nestle so far has quadrupled while the number of small farmers selling milk to Nestle has trebled. This simple innovation has not only made the BOP market more productive and efficient but has had a far-reaching economic and social impact that extends beyond the farmers themselves. In the process, Nestle has created hundreds of jobs and directly affected about a million small farmers and their families by ensuring that the product of the poor (milk) is bought directly from the poor, processed and packed into value-added products like yogurt, powdered milk and other dairy products, and sold to middle and higher income groups in the economic pyramid. This has empowered the BOP not as consumers but as producers and helped improve their livelihood by removing poverty and gaining a significant market share while making profits in the process.

\subsection{Tata Nano}

Tata Nano (2013) is the brain child of the visionary entrepreneur Ratan Tata, Chairman of the Tata Group, a multinational Indian conglomerate. He envisaged a car for the people at the BOP in India who did not have the means to buy the existing conventional cars yet represented a significant market opportunity. His dream was realised through the manufacture of the world's cheapest car, also called the "1-lac" car as it costs only 100000 Indian rupees ( $1 \mathrm{lac}$ ), the equivalent of roughly 2,500 US\$. The product was not simply a business model innovation that created a completely new market, but was also a technological marvel in that it was the world's most fuel-efficient car (22 km per litre) in which all non-essential functions had been removed (Farris, Lemley \& Venkatesan, 2009). Tata Nano was the most keenly awaited and talked about car of 2008 and had all the characteristics of a disruptive innovation. It was designed to be safe, affordable and an allweather vehicle for families at the bottom of the economic pyramid through a combination of radical re-engineering of automotive design, manufacturing and supply chain relationships (Chakravarthy \& Coughlan, 2012). It was intended to disrupt the market for used cars and motorcycles initially and significantly reduce the sales of its closest competitor, the Maruti. Despite having all the characteristics of success, Tata Nano ended up being a commercial failure as it did not achieve target sales - which kept declining over time. Before Tata Nano was launched, monthly sales of 20 000 units were predicted but the car could only sell 509 units in November 2009. The sales recovered to 10000 units per month at the start of 2011 but dropped to 3,260 units again by July of the same year. Early on, two cars caught fire, which gave rise to safety concerns among potential customers for Tata Nano although these concerns were resolved soon afterwards and the accidents could not be attributed to the technical failure of the car in general. Later on price also became a stumbling block to rises in car sales as the price was increased by 15 per cent, making the car unaffordable to the customers at the BOP for whom it had been intended. Analysts have associated many factors with the failure, including political and geographic reasons, which made it necessary to relocate the manufacturing site and hence delay product delivery. There was a marketing failure in the form of a lack of understanding of market 
demographics and customer perception, along with technical drawbacks and a failure to meet the basic needs of the new market. According to Tiwari and Herstatt (2012), the failure was caused by customer perceptions of defects in quality and the social stigma associated with driving a "cheap" car. The manufacturers see this as a valuable marketing lesson: instead of the marketing campaign projecting Tata Nano as the cheapest car on the market, its innovative aspects and international standards of quality should have been emphasised. As noted by Chakravarthy and Coughlan (2012), failure despite product innovation was the result of Tata's lack of business system innovation in aligning sales, marketing, distribution, financing and service arrangements with the value proposition offered to the customers by the product itself. In contrast, Tata Ace, a $\$ 5000$ commercial vehicle costing 50 per cent less than any other commercial vehicle in India and designed to be low cost, low maintenance, fuel efficient and rugged enough to suit Indian roads while offering the safety of a fourwheeler has been a great success for Tata motors. The Tata Ace has created a market with 54 per cent non-consumers and rolled out 100000 vehicles within 22 months of launch (Tiwari \& Herstatt, 2012).

\subsection{Grameen Bank}

Muhammad Yunus, an Economics Professor at Chittagong University in Dhaka (Bangladesh), while engaging in farming projects with villagers of Jobra Village in 1976, realised that the greatest hurdle the poor locals faced in economic growth was access to credit. He started a microlending project engaging the women primarily, as they are the principal breadwinners of the families and also better credit risks than men. Small loans are made to groups of women, usually five in number, and the responsibility for repaying the loans rests with the entire group rather than with individuals (Subrahmanyan \& Gomez-Arias, 2008). By engaging local groups to vouch for the credibility of the people taking loans, this model managed to create a completely disruptive microcredit financial system entirely different from the conventional ones. In this case the vast majority of poor people had access to smaller loans according to their needs. The loans were then invested by these women in small businesses that generate revenue for them. These loans helped them improve their lives and yielded promising returns, which allowed for sustainability and made it possible to offer loans to more and more people. Even though no collateral is held, the model is quite successful and enables a high rate of return because of collective group trust and cohesion. Grameen's banking model is recognised as one of the most disruptive social entrepreneurial models of current times that has been adopted worldwide and has helped millions of people improve their lives and the economic health of communities through access to small loans. Muhammad Yunus, the founder of Grameen Bank, received a Nobel Peace Prize in 2006 for his achievement and is known as the father of microcredit (Martin \& Osberg, 2007; Simanis \& Hart, 2008). Grameen's (2013) model has been successful against all odds. Less than 100 out of a total of 7000 microfinance institutions have been able to achieve self-sufficiency with a repeatable and scalable business model, fewer still are able to generate profits (Karnani, 2007). Apart from the apparent economic benefits for the people at the BOP, microcredit also provides social benefits like self-esteem, social cohesion and the empowerment of women. It helps these people to smooth out expenses and consumption during unexpected financial crises. In the long run, it acts as an enabler and helps reduce poverty, encouraging people to eventually become self-dependent producers. The profits generated by microcredit are used to engage in new social ventures, like Grameen Telecom and Grameen Energy (Mair \& Marti, 2006). The Grameen telephone enterprise, which was initiated in 1997 in 950 villages with the help of "phone lady" entrepreneurs who sold mobile services in the villages, showed immense growth and reached a revenue of $\$ 1$ billion and net profits of $\$ 200$ million by 2008 (Simanis \& Hart, 2008).

\subsection{SKS Microfinance}

Based on an almost exactly similar model to that of Grameen Bank, SKS Microfinance (2013) is an Indian finance company that provides microfinance to the poor. Founded in 
1997 by Vikram Akula in India, the company did reasonably well in the initial years. It applied modern financial management principles in microcredit such as the use of back office systems. Risk profiles were also monitored carefully by balancing loan payments in different sectors, When a lot of people took out loans for buffalos (a native ox), for example, this was balanced by lending in other sectors, such as construction, auto repair or retail (Subrahmanyan \& GomezArias, 2008). SKS microfinance has an extensive branch network in many Indian states and has partnered Nokia to help finance the purchase of cell phones at the BOP (Chakravarthy \& Coughlan, 2012). In 2008, SKS Microfinance was the largest microfinance institution in India, with the highest numbers of borrowers, branches and loans. However, the company went through a major financial crisis in recent years when almost all the borrowers in one of India's largest states stopped repaying their loans. The microfinance industry was even criticised by the politicians for making money off the poor as they were granting loans to poor villages at very high interest rates regardless of ability to repay those loans. Some Indian analysts even feared that this was a financial disaster as big as America's subprime mortgage crisis and that it could affect the global economy as well as Indian banks, which had about $\$ 4$ billion tied up in the microfinance industry (Polgreen \& Bajaj, 2010). The microfinance model of SKS not only had economic implications but also led to social disasters like suicides. One of the main reasons advanced for the failure was SKS's primary focus on profits rather than on social value. They were not ensuring economic sustainability by limiting their incomegenerating activities but simply trying to make money by any means possible. The potential of a rise in stock market listing and investments by private equity firms encouraged SKS to grant as many loans as possible.

\section{5}

\section{Discussion}

As the case studies indicate, similar attempts at innovation or social enterprise models have yielded different results altogether in terms of their social and economic impacts. The variations in similar cases and how they led to these outcomes need to be analysed in the light of academic literature to define key factors that enable the economic and social success of innovations or social enterprises at the BOP. An innovation or enterprise would be regarded as a social success if it is able to provide a social benefit to the BOP community with its offering and an economic success if the enterprise is able to meet its economic needs to ensure a sustainable and scalable model or in certain cases if it is able to enhance the economic benefits both for itself and for the BOP community. The reason for taking failures into account in addition to successes is that "we often learn more from innovation failure than from innovation success" (Yapp, 2005). While successes reveal all the probable criteria that could have provided a recipe for success, failure clearly identifies the criteria to avoid in order to escape failure.

\subsection{Beyond selling to the poor}

According to Simanis and Hart (2008), the way most multinational companies have approached the BOP has been flawed. They argue that the BOP is a socio-economic demographic rather than a market where apparently simple needs are complicated because of their immersion in the social structure. It requires business development processes in synchronisation with the BOP community (instead of forecasting the demand) so that the value proposition offered is developed in alignment with the actual needs of the community (Simanis \& Hart, 2008). A basic unsuccessful approach by companies targeting the BOP has been to provide "stripped down products" simply by removing features from the products sold to developed markets whereas what was required was a redesign according to the needs of the BOP consumers (Subrahmanyan \& Gomez-Arias, 2008). Companies have failed to realise that BOP consumers are themselves sophisticated and require quality products at an affordable price. Success, however, lies in reducing not just the initial price but the total cost of ownership and customers' increased perception of quality and image of the product or service being offered (Tiwari \& Herstatt, 2012). The 
objective of these companies has been to make as much money as possible as quickly as possible, a narrow vision which has led to unexpected results. BOP has to be thought of as more than a quick money-making venture and there have to be considerations "beyond selling to the poor" to achieve the desired results (Simanis \& Hart, 2008). In other words, it is not unethical to sell to the poor if basic necessities of "usefulness" and "affordability" are provided for and "value creation for BOP" is at the heart of the offering (Unite For Sight, 2013).

\subsection{BOP as producers}

Another important factor pointed out by key academics in the BOP field is that of treating "BOP as producers rather than consumers" for success (Hall et al., 2012; Karnani, 2007). Instead of selling to the BOP, the focus should be on buying from them. The narrative needs to be "creating a fortune with the BOP" rather than "finding a fortune at the BOP" (London \& Anupindi, 2012). The BOP needs to be considered as a source of self-sufficient producers and consumers who can design and produce products and services not only for their own market but for mature markets as well. Accepting and utilising the BOP as producers or entrepreneurs and not just consumers offers the best opportunity not only to uplift them from poverty but also to create an economically sustainable and profitable business model. Instead of merely selling to them, strengthening them as producers by investing in their skills or productivity improvement and creating job opportunities for them can create a win-win scenario. If the reach of their products and services is efficiently extended to developed markets, this can create an ideal opportunity and unleash the real fortune at the bottom of the pyramid.

\subsection{BOP engagement}

A major criterion for achieving success at the BOP is through "BOP engagement" or engaging with the community to identify and clearly understand their problems and needs and potentially partnering with the community in "co-creating" products and services for BOP needs (London \& Anupindi, 2012). The double-edged objective of creating a new market at the BOP while helping the poor in the market to be lifted out of poverty can be achieved by successful collaboration between companies and local parties in developing countries (Grootveld, Vermeulen, \& Geurts, 2008). According to Simanis and Hart (2008), the new B2C strategy for companies dealing with bottom of the pyramid markets is "Business to Community" rather than "Business to Consumer". This is because the entire approach and mindset need to be changed to one of engaging with the local community by becoming part of them and forming strong relationships rather than thinking of them as consumers. This engagement cannot be a single-sided process as in collecting data for market research, but requires dedication in understanding the problems of the community.

\section{6}

\section{Findings}

The case studies discussed will now be analysed for economic and social success on the basis of the criteria defined. Nestle Pakistan deeply engages the poor at the BOP by empowering them as producers instead of making them consumers and selling their product to the developed markets. It is both an economic and a social success. Tata Nano, although primarily a concept that went beyond selling to the poor by bringing a product within the reach of their buying power, was unable to engage the BOP and could not include the poor as producers by offering job opportunities within their communities. It was an initial economic and social failure. Grameen Bank also aimed at a concept that went beyond selling to the poor as it is a not-for-profit organisation and the profits on interest are used to provide further loans and to invest in other similar businesses such as Grameen phone. Even though the BOP is not a producer in Grameen's case, there is a high level of engagement and immersion that has enabled both economic and social success. SKS Microfinance, as a for-profit entity focused on maximising the returns on investment without engaging the poor at the BOP, was soon perceived as a venture for making money from the poor. The result was a halt in the repayment of loans and even suicides in certain 
cases, making it an economic and social failure.

Table 1 shows an analysis of the case studies discussed on the basis of defined success criteria for the bottom of the pyramid. It is evident from the table that among the three defined criteria of "beyond selling to the poor", "BOP as producers" and "BOP engagement", at least two are required to enable an innovation or social venture at the bottom of the pyramid to achieve economic and social success. The most important criterion has been "BOP engagement", which has been present to some extent in all the successes and missing in all the failures among the case studies considered. Hence, "engagement" can be a key deal breaker for innovation and social enterprise success at the BOP.

Table 1

Analysing case studies on BOP success

\begin{tabular}{|c|c|c|c|c|c|}
\hline Case studies & $\begin{array}{l}\text { Beyond selling } \\
\text { to the Poor }\end{array}$ & $\begin{array}{l}\text { BOP as } \\
\text { producers }\end{array}$ & $\begin{array}{c}\text { BOP } \\
\text { engagement }\end{array}$ & Social success & $\begin{array}{l}\text { Economic } \\
\text { success }\end{array}$ \\
\hline Nestle Pakistan & $\checkmark$ & $\checkmark$ & $\checkmark$ & $\checkmark$ & $\checkmark$ \\
\hline Tata Nano & $\checkmark$ & $x$ & $x$ & $x$ & $x$ \\
\hline Grameen Bank & $\checkmark$ & $x$ & $\checkmark$ & $\checkmark$ & $\checkmark$ \\
\hline SKS Microfinance & $\mathbf{x}$ & $\mathbf{x}$ & $\mathbf{x}$ & $\mathbf{x}$ & $\mathbf{x}$ \\
\hline
\end{tabular}

Source: Compiled by author

7

\section{Conceptual Framework}

A conceptual framework reflecting the success of innovations or social enterprises at the bottom of the pyramid is provided in Figure 1. This is based on the criteria defined with the help of academic literature and an analysis of case studies done on the defined criteria.

Figure 1

Conceptual framework reflecting innovation and social enterprise success at BOP

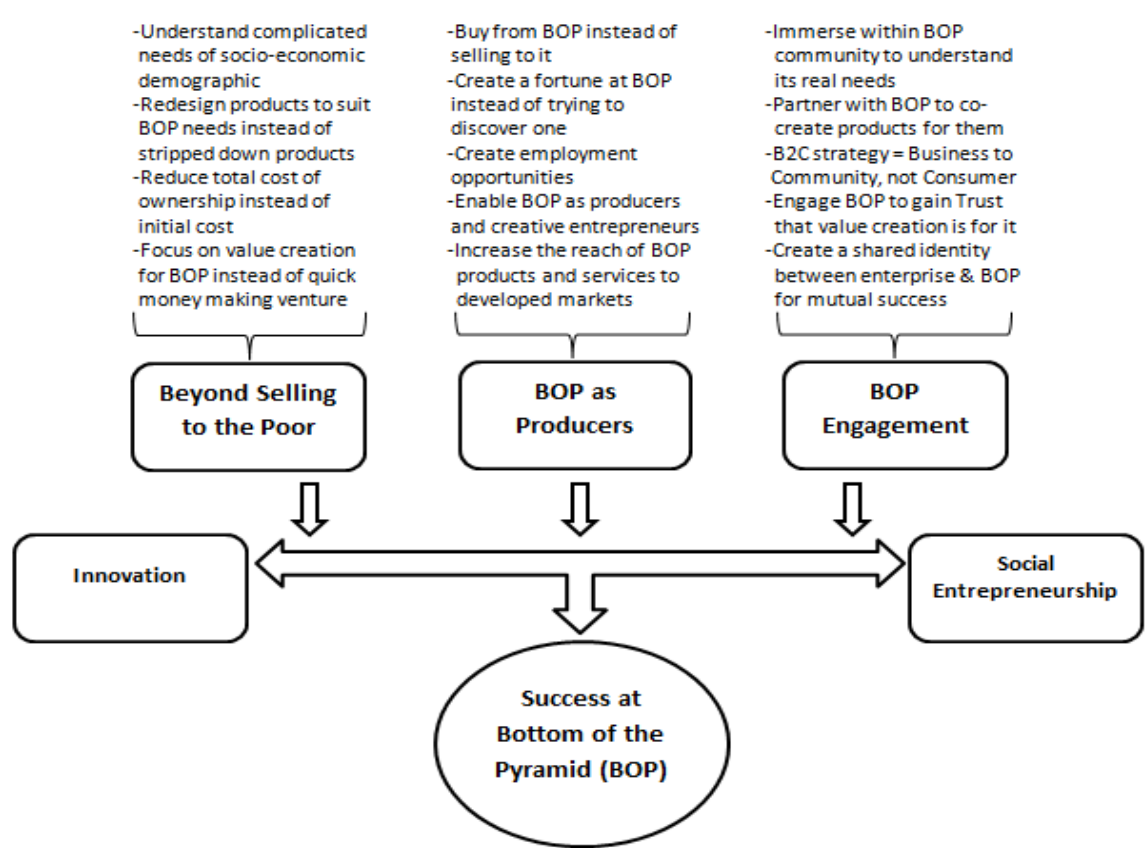

Source: Compiled by author; adapted from (Grootveld et al., 2008; Hall et al., 2012; London \& Anupindi, 2012; Simanis \& Hart, 2008a; Subrahmanyan \& Gomez-Arias, 2008; Tiwari \& Herstatt, 2012; von Hippel et al., 2012) 
As discussed in detail in the sections "5.1 Beyond selling to the poor"; "5.2 BOP as producers" and "5.3 BOP engagement", these success criteria emerged as key determinants from the extant literature. The first criterion "beyond selling to the poor" (Simanis \& Hart, 2008; Subrahmanyan \& Gomez-Arias, 2008; Tiwari \& Herstatt, 2012) entails developing the BOP successfully in both social and economic terms by offering value to the poor in the market that goes beyond a mere selling or money-making venture. These demographics involve complex needs that need to be fully understood in designing the right solutions for them - and these solutions cannot be stripped down versions of solutions that work in developed markets. Success lies in reducing not only initial costs but also the total cost of ownership for the poor.

The second important criterion for success is to not target the poor people at the bottom of the pyramid as consumers but to encourage "BOP as producers" (Hall et al., 2012; London \& Anupindi, 2012; Von Hippel, de Jong, \& Flowers, 2012). This can be achieved by engaging them as entrepreneurs and enhancing their product or service reach to developed markets, or designing a BOP product or service chain that will offer employment opportunities to the poor who can take ownership of the BOP value proposition and ensure its success. To achieve this, the people at the BOP have to be accepted as reliable and self-sufficient producers and entrepreneurs who can take on the challenge of selfimprovement.

The third and most important criterion to emerge from the case studies is "BOP engagement" (Grootveld et al., 2008; London \& Anupindi, 2012; Simanis \& Hart, 2008), which implies that to completely understand the needs of the BOP market consumers, an enterprise needs to collaborate fully with and immerse itself in the BOP community. This enables trust between the enterprise and the BOP, allowing a shared identity between the two with resultant co-creation or codevelopment of solutions that fit BOP needs in an attempt to achieve joint success. This critical criterion was found to be the key differentiator among the case studies on innovations and social ventures at the BOP discussed in this paper.

As observed in the Findings section, a combination of three criteria can significantly enhance the chances of success of innovations by social or corporate enterprises at the complex bottom of the economic pyramid market.

\section{8}

\section{Conclusion and recommendations}

The major difference between the success and failure of innovation and social entrepreneurship models at the BOP has been found to be the perceived value by the BOP market. The first important criterion identified for success is the perception of an enterprise's efforts "beyond selling to the poor". It is essential in any business that value creation is for the entire chain of stakeholders, including customers and shareholders. However, when operating at the base of the pyramid it becomes particularly important to focus primarily on value creation for the customers or BOP consumers, beyond just focusing on profits and attempting quick money-making ventures. A win-win scenario can be achieved with the help of the second identified success criterion, namely considering "BOP as producers" rather than consumers. This not only abolishes the perception of selling to the poor, but also empowers the people at the BOP as entrepreneurs by providing them with economic and social opportunities for mutual growth and linking them to developed markets. This eventually results in remarkable economic returns for the enterprise as well. To be sustainable, the product or service needs to be designed to give the chosen market access to an otherwise unattainable experience. This can only be truly achieved by complete "BOP engagement". The enterprise needs to embed or immerse itself within the BOP community to fully understand its needs, develop trust and a shared identity with the potential consumers in order to co-develop according to their needs so that the value offered is perceived as a collaborative economic and social success by both BOP and the enterprise. By adopting these success criteria, enterprises are able not only to enhance chances of innovation success at the BOP but also to be more responsible and 
socially inclusive by elevating millions from poverty. The proposition, therefore, is "creating fortune at the bottom of the pyramid" that is based on mutual social and economic gains for the BOP and the enterprise rather than a treasure hunt for enterprises aimed at "finding fortune at the bottom of the pyramid".

This research has been limited by constraints of time and resources to a deskbound study based on secondary data. The recommendation for further work is to take the concluding success criteria from this conceptual framework and use them as a hypothesis for empirical research. By devising research that empirically tests the framework, and using primary qualitative or quantitative analysis, the hypothesis can be proved or disproved or the theory can be modified to reach a 'BOP success model for innovations and social enterprises'.

\section{Acknowledgement}

The authors are grateful to the valuable comments made by the reviewers.

*CORRESPONDING AUTHOR CONTACT

Alex Maritz, amaritz@swin.edu.au

\section{References}

AHLSTROM, D. 2010. Innovation and growth: how business contributes to society. The Academy of Management Perspectives:10-23. |Available at: http://amp.aom.org/content/24/3/11.short [accessed 2013-09-29].

AUSTIN, J., STEVENSON, H. \& WEI-SKILLERN, J. 2006. Social and commercial entrepreneurship: same, different, or both? Entrepreneurship theory .... Available at: http://onlinelibrary.wiley.com/doi/10.1111/ j.1540-6520.2006.00107.x/full [accessed 2013-09-29].

BAREGHEH, A., ROWLEY, J. \& SAMBROOK, S. 2009. Towards a multidisciplinary definition of innovation. Management Decision, 47(8):1323-1339. Available at: doi:10.1108/00251740910984578 [accessed 2013-09-29].

BECKER, S. \& WHISLER, T. 1967. The innovative organization: a selective view of current theory and research. The Journal of Business, 40(4):462-9. Available at: http://www.jstor.org/stable/10.2307/2351628 [accessed 2013-09-29].

CHAKRAVARTHY, B. \& COUGHLAN, S. 2012. Emerging market strategy: innovating both products and delivery systems. Strategy \& Leadership, 40(1):27-32. Available at: doi:10.1108/10878571211191675 [accessed 2013-09-29].

CROSSAN, M.M. \& APAYDIN, M. 2010. A multi-dimensional framework of organizational innovation: a systematic review of the literature. Journal of Management Studies, 47(6):1154-1191. Available at: doi:10.1111/j.1467-6486.2009.00880.x [accessed 2013-09-29].

DAMANPOUR, F. \& SCHNEIDER, M. 2008. Characteristics of innovation and innovation adoption in public organizations: assessing the role of managers. Journal of Public Administration Research and Theory, 19(3):495-522. Available at: doi:10.1093/jopart/mun021[accessed 2013-09-29].

DEES, J. 1998. The meaning of social entrepreneurship. ... the Social Entrepreneurship Funders Working Group, ...:1-6. Available at: http://onlinelibrary.wiley.com/doi/10.1002/cbdv.200490137/abstract [accessed 2013-09-29].

EISENHARDT, K. 1989. Building theories from case study research. Academy of Management Review, 14(4):532-550. Available at: http://www.jstor.org/stable/10.2307/258557 [accessed 2013-09-29].

EMPSON, R.I.P. 2012. Clayton Christensen : Disruptive innovations create jobs, efficiency innovations destroy them:9-10. Available at: http://techcrunch.com/2012/10/09/clayton-christensen-disruptiveinnovations-create-jobs-efficiency-innovations-destroy-them/ [accessed 2013-09-29].

FARRIS, P., LEMLEY, A. \& VENKATESAN, R. 2009. The Tata Nano: the people's car. Available at: http://papers.ssrn.com/sol3/papers.cfm?abstract_id=1420597 [accessed 2013-09-29].

GRAMEEN BANK. 2013. Available at: www.grameen.info.org [accessed 2013-09-12]. 
GOVINDARAJAN, V. \& RAMAMURTI, R. 2011. Reverse innovation, emerging markets, and global strategy. Global Strategy Journal, 205:191-205. Available at: doi:10.1111/j.2042-5805.2011.00023.x [accessed 2013-09-29].

GROOTVELD, P., VERMEULEN, P. \& GEURTS, J. 2008. Strategies for the base-of-the-pyramid. baseofthepyramid.nl. Available at: http://www.baseofthepyramid.nl/docs/Becoming trusted at the base-ofthe-pyramid.pdf [accessed 2013-09-29].

HALL, J., MATOS, S., SHEEHAN, L., \& SILVESTRE, B. 2012. Entrepreneurship and innovation at the base of the pyramid: a recipe for inclusive growth or social exclusion? Journal of Management Studies, 49(4):785-812. Available at: doi:10.1111/j.1467-6486.2012.01044.x [accessed 2013-09-29].

HAMMOND, A.L., KRAMER, W.J., KATZ, R.S., TRAN, J.T. \& WALKER, C. 2007. The next 4 billion. Innovations: Technology, Governance, Globalization, 2(1-2):147-158. Available at: doi:10.1162/itgg. 2007.2.1-2.147 [accessed 2013-09-29].

KARNANI, A. 2007. Fortune at the bottom of the pyramid: a mirage: How the private sector can help alleviate poverty, (1035). Available at: http://scholar.google.com/scholar?hl=en\&btnG=Search\& $\mathrm{q}=$ intitle:Fortune + at + the + Bottom + of + the + Pyramid $+:+$ A + Mirage + How + the + private + sector + can + help + allevi ate+poverty\#1[accessed 2013-09-29].

LONDON, T. \& ANUPINDI, R. 2012. Using the base-of-the-pyramid perspective to catalyze interdependence-based collaborations. Proceedings of the National Academy of Sciences of the United States of America, 109(31):12338-43. Available at: doi:10.1073/pnas.1013626108 [accessed 2013-09-29].

MAIR, J. \& MARTI, I. 2006. Social entrepreneurship research: a source of explanation, prediction, and delight. Journal of World Business, 3(546). Available at: http://www.sciencedirect.com/science/article/pii/ S1090951605000544 [accessed 2013-09-29].

MARKIDES, C. 2012. How disruptive will innovations from emerging markets be? MIT Sloan Management Review, 18 September:1-7. Available at: http://sloanreview.mit.edu/the-magazine/2012-fall/54120/howdisruptive-will-innovation... [accessed 2013-09-29].

MARTIN, R. \& OSBERG, S. 2007. Social entrepreneurship: the case for definition. Stanford Social Innovation Review. Available at: http://www.ngobiz.org/picture/File/Social Enterpeuneur-The Case of Definition.pdf [accessed 2013-09-29].

NESTLE. 2013. Nestle Pakistan milk collection. Available at: http://www.nestle.pk/aboutus/milkcollection [accessed 2013-05-15].

POLGREEN, L. \& BAJAJ, V. 2010. India microcredit faces collapse from defaults. New York Times:1-5. Available at: http://relooney.fatcow.com/0_NS4053_1159.pdf [accessed 2013-09-29].

PRAHALAD, C. \& HART, S. 2002. The fortune at the bottom of the pyramid. Strategy and Business, (48): 1-23. Available at: http://docs.swansatfoundation.com/files/008_pyramid.pdf [accessed 2013-09-29].

ROGERS, M. 1998. The definition and measurement of innovation. Available at: http://citeseerx.ist.psu.edu/ viewdoc/download?doi=10.1.1.194.4269\&rep=rep1\&type=pdf [accessed 2013-09-29].

SAUNDERS, M. 2012. Research methods for business students. Available at: http://ensor.lib.strath.ac.uk/ sfxlc141?ctx_ver=Z39.88-2004\&ctx_enc=info:ofi/enc:UTF-8\&ctx_tim=2013-05-20T13:13:00IST\&url ver=Z39.88- 2004\&url_ctx_fmt=infofi/fmt:kev:mtx:ctx\&rfr_id=info:sid/primo.exlibrisgroup.com:primo3Journal-SUVOY\&rft_val_fmt=info:ofi/fmt:kev:mtx:book\&rft.genre=book\&rft.atitle=\&rft.jtitle=\&rft.btitle= Research methods for business students\&rft.aulast=Saunders\&rft.auinit $=\& \mathrm{rft}$.auinit $1=\& \mathrm{rft}$.auinitm $=\& \mathrm{rft}$. ausuffix $=\& r f t$.au=Saunders, Mark, 1959-\&rft.aucorp=\&rft.volume=\&rft.issue=\&rft [accessed 2013-09-29]. SHAH, A. 2008. Poverty facts and stats. Global Issues:1-7. Available at: http://www.bunburycatholic.wa. edu.au/home/sdrive/Religious_Education/TEE_Prep/Resources/Poverty_Facts_and_Stats.docx [accessed 2013-09-29].

SKS MICROFINANCE. 2013. Available at: www.sksindia.com [accessed 2013-09-12].

SIMANIS, E. \& HART, S. 2008. Beyond selling to the poor: building business intimacy through embedded innovation. Johnson School of Management, Working Paper, .... Available at: http://erb.umich.edu/Research/ Initiatives/colloquiaPapers/Simanis Hart Embedded Innovation Revised Final.pdf [accessed 2013-09-29]. SUBRAHMANYAN, S. \& GOMEZ-ARIAS, J. T. 2008. Integrated approach to understanding consumer behavior at bottom of pyramid. Journal of Consumer Marketing, 25(7):402-412. Available at: doi:10.1108/ 07363760810915617 [accessed 2013-09-29].

TATO NANO. 2013. Available at: www.tatonano.com [accessed 2013-09-12]. 
THOMPSON, V. 1965. Bureaucracy and innovation. Administrative Science Quarterly, 10(1):1-20. Available at: http://www.jstor.org/stable/10.2307/2391646 [accessed 2013-09-29].

TIWARI, R. \& HERSTATT, C. 2012. Technology and innovation management open global innovation networks as enablers of frugal innovation: propositions based on evidence from India, 66(3):245-274.

UNITE FOR SIGH 2013. Business at the base of the pyramid (BOP). Available at: http://www.uniteforsight. org/social-entrepreneurship-course/module9 [accessed 2013-04-20].

VON HIPPEL, E., DE JONG, J.P.J. \& FLOWERS, S. 2012. Comparing business and household sector innovation in consumer products: findings from a representative study in the United Kingdom. Management Science, 58(9):1669-1681. Available at: doi:10.1287/mnsc.1110.1508 [accessed 2013-09-29].

VOROS, J. 2008. Integral futures: an approach to futures inquiry. Futures, 40(2):190-201. Available at: doi:10.1016/j.futures.2007.11.010 [accessed 2013-09-29].

WONG, A., TJOSVOLD, D. \& LIU, C. 2009. Innovation by teams in Shanghai, China: cooperative goals for group confidence and persistence. British Journal of Management, 20(2):238251. Available at: doi:10.1111/ j.1467-8551.2008.00563.x [accessed 2013-09-29].

YAPP, C. 2005. Innovation, futures thinking and leadership. Public Mmoney and Management, May 2013:37-41. Available at: http://www.tandfonline.com/doi/abs/10.1111/j.1467-9302.2005.00451.x [accessed 2013-09-29].

YIN, R.K. 1981. The case study as a serious research strategy. Science Communication, 3(1):97-114. Available at: doi:10.1177/107554708100300106 [accessed 2013-09-29]. 